\title{
ANALISIS KESALAHAN BERBAHASA DALAM LAPORAN PERTANGGUNGJAWABAN OSIS DI SMP NEGERI 4 KOTA SUKABUMI
}

\author{
Purwansyah Deffy Dwigantara \\ PBSI FKIP Universitas Muhammadiyah Sukabumi \\ deffypurwansyah123@gmail.com
}

David Setiadi

Dosen PBSI FKIP Universitas Muhammadiyah Sukabumi

idaites10@gmail.com

\section{Hera Wahdah Humaira}

Dosen PBSI FKIP Universitas Muhammadiyah Sukabumi

Hera297@ummi.ac.id

\begin{abstract}
Abstrak: penelitian ini dilatarabelakangi oleh analisis kesalahan berbahasa dalam laporan pertanggungjawaban Osis di SMP Negeri 4 Kota Sukabumi. Dalam penelitian ini peneliti menganalisis mengenai ejaan dan kata baku pada laporan pertanggungjawaban Osis di SMP Negeri 4 Kota Sukabumi. Penelitian ini bertujuan untuk mengetahui sejauh mana siswa dalam menulis laporan pertanggungjawaban OSIS. Metode dalam penelitian ini menggunakan metode kualitatif dengan teknik pengumpulan data observasi, wawancara, dan dokumentasi. Hasil penelitian menunjukkan bahwa kesalahan ejaan pada laporan pertanggungjawaban osis dapat dilihat sebagai berikut, berupa kesalahan penggunaan tanda baca, kata depan, dan huruf kapital penulisan huruf capital yang berada di tengah kalimat sebelum tanda baca titik (.) yaitu terdapat pada kata "Hari", "Siswa" yang seharusnya dalam EBI adalah "hari", "siswa". Kemudian, pada penulisan kata kesalahan ditemukan pada penggunaan kata baku sebagai berikut terdapat kesalahan pada kata "Shalat" yang seharusnya dalam EBI adalah "Salat" karena kata pertama itu merupakan kata tidak baku. Berdasarkan hasil penelitian ini kesalahan yang paling banyak ditemukan yaitu kesalahan pada penggunaan tanda baca dan huruf kapital.

Kata kuncsssi: laporan, ejaan, kata baku.
\end{abstract}

History :

Submit tgl 25 Juni 2020, review 6 Juli 2020, accepted 6 Juli 2020 


\section{Pendahuluan}

Setiap pemakai bahasa Indonesia menginginkan dapat menggunakan bahasa Indonesia dengan baik dan benar. Namun, kita sering membuat kesalahan dan tidak tahu bagaimana seharusnya bahasa itu digunakan. Seseorang yang menggunakan bahasa yang baik akan memperlihatkan hubungan logis antara bahasa yang digunakan dan pikiran yang terkandung dalam bahasa itu. Dengan demikian, penutur dan petutur akan mudah menangkap apa yang telah disampaikan .

Keterampilan bahasa Indonesia erat kaitannya dengan empat keterampilan berbahasa yaitu menulis, membaca, berbicara, menyimak. Salah satu keterampilan yang harus dimiliki oleh seseorang adalah keterampilan menulis. Menulis merupakan salah satu aspek penting dalam keterampilan berbahasa. Menulis merupakan kemampuan dasar yang harus dimiliki seseorang untuk digunakan dalam kehidupan sehari-hari.

Sementara itu, Tarigan (2008: 3) berpendapat bahwa, menulis merupakan suatu keterampilan berbahasa yang dipergunakan untuk berkomunikasi secara tidak langsung, tidak secara tatap muka dengan orang lain. Menulis merupakan suatu kegiatan yang produktif dan ekpresif. Menulis sebagai kegiatan yang produktif karena menulis merupakan kegiatan yang ekpresif dikarenakan menulis mampu memberikan atau mengungkapkan suatu gambaran, gagasan, maksud maupun perasaan.

Bahasa tulis dapat diartikan ke dalam bahasa yang diucapkan yang kemudian ditulis.
Menulis merupakan suatu keterampilan berbahasa dalam pembelajaran berbahasa Indonesia. Dalam menulis kadang ditemukan kata-kata berbagai macam, ada kata baku dan kata tidak baku. Kata baku merupakan kata yang sesuai dengan Ejaan Bahasa Indonesia (EBI). Begitu sebaliknya dengan kata tidak baku. Kadang ditemukan bahasa atau kata yang tidak baku dalam sebuah laporan kegiatan.

Berdasarkan penelitian sebelumnya, peneliti akan menganalisis penggunaan ejaan dan kata baku dalam laporan pertanggung jawaban OSIS di SMP Negeri 4 Kota Sukabumi Tahun Pelajaran 2018/2019. Dengan demikian, penelitian ini akan direncanakan berjudul "Analisis Kesalahan Berbahasa dalam Laporan Pertanggungjawaban OSIS di SMP Negeri 4 Kota Sukabumi Tahun Pelajaran 2018/2019”.

\section{METODE PENELITIAN}

Penelitian ini menggunakan penelitian kualitatif dengan menggunakan metode deskriprif. Menurut Sugiyono (2016: 1), metode penelitian adalah cara ilmiah untuk mengumpulkan data yang memiliki tujuan dan kegunaan tertentu. Dalam metode penelitian terdapat dua jenis metode penelitian yaitu metode penelitian kuantitatif dan metode penelitian kualitatif.

Metode kualitatif digunakan untuk mendapatkan data yang mendalam dan mengandung makna yang sebenarnya. Akhir penelitian pada kualitatif bukan hanya untuk 
mendapatkan informasi yang dicari, tetapi harus mampu menghasilkan informasi yang bermakna terhadap masalah penelitian yang serupa. Pada penelitian kualitatif, akan terjadi tiga kemungkinan terhadap masalah yang dibawa oleh peneliti dalam penelitian

\section{HASIL DAN PENELITIAN}

Berdasarkan temuan Berdasarkan temuan penelitian yang telah dilakukan, peneliti mengumpulkan data-data melalui observasi untuk dianalisis berdasarkan kebutuhan analisis dalam pembahasan penggunaan ejaan, kata, dan kalimat. maka dapat diketahui kesalahan penggunaan ejaan, kata, kalimat Bahasa Indonesia yang akan dibahas pada bagian di bawah ini.

\section{Tabel 1}

\begin{tabular}{|l|l|l|}
\hline No & Kesalahan & Sesuai EBI \\
\hline 1 & Disekolah & di sekolah \\
\hline 2 & Sebagai & sebagai \\
\hline 3 & $\ldots$ tersebut,timbulah... & $\begin{array}{l}\ldots \text { tersebut } \\
\text { timbulah... }\end{array}$ \\
\hline 4 & Diantara & di antara \\
\hline 5 & Disusun & di susun \\
\hline 6 & di gunakan & Digunakan \\
\hline 7 & berkitan & Berkaitan \\
\hline 8 & dasar Hukum & dasar hukum \\
\hline 9 & ...sukabumi.Periode... & $\begin{array}{l}\text {...sukabumi } \\
\text { periode... }\end{array}$ \\
\hline \multicolumn{2}{|c|}{ Berdasarkan data di atas, terdapat }
\end{tabular}

kesalahan ejaan dalam penggunaan tanda baca titik (.) dan penggunaan huruf kapital di tengah kalimat. Kemudian terdapat kesalahan penggunaan kata depan. Seperti terdapat pada kata "Disekolah" yang sesuai EBI seharusnya ditulis "di sekolah" karena kata depan yang diikuti dengan menunjukkan tempat yang terdapat pada baris ke dua. Kesalahan lainnya terdapat kata "Sebagai" yang sesuai EBI seharusnya di tulis "sebagai" karena berada di tengah kalimat dan tidak ada tanda baca titik (.) pada kalimat sebelumnya untuk menandai akhir kalimat yang terdapat pada baris ke-lima. Kesalahan lainnya pada kata “...tersebut,timbulah..." yang sesuai EBI seharusnya di tulis "... tersebut timbulah..." yang terdapat pada baris ke-enam.

Selanjutnya, kesalahan lainnya pada kata "Diantara" yang sesuai EBI seharusnya di tulis "di antara" karena kata depan yang diikuti dengan menujukkan sesuatu yang terdapat pada baris ke-11. Kesalahan lainnya pada kata "Disusun" yang sesuai EBI seharusnya di tulis "di susun" yang terdapat pada baris ke-23. Kesalahan lainnya pada kata "di gunakan" yang sesuai EBI seharusnya di tulis "Digunakan" yang terdapat pada baris ke-26. Kesalahan lainnya pada kata "berkitan" terdapat kesalahan dalam penulisan yang seharusnya sesuai dengan EBI di tulis "Berkaitan" yang terdapat pada baris ke-28. Kemudian, kesalahan pada kata "dasar Hukum" yang sesuai EBI seharusnya di tulis "dasar hukum" karena penulisan yang seharusnya di tengah kalimat tidak menggunakan huruf kapital yang terdapat pada baris ke-30. Terdapat kesalahan lainnya pada kata “...sukabumi.periode..." yang sesuai EBI seharusnya di tulis “...sukabumi periode..." karena seharunya tidak menggunakan tanda baca titik (.) yang terdapat pada baris ke-31 .

\section{Tabel 2}

\begin{tabular}{|l|l|l|}
\hline No & Kesalahan & Sesuai EBI \\
\hline
\end{tabular}




\begin{tabular}{|l|l|l|}
\hline 1 & $\ldots$. tersedia & ...tersedia. \\
\hline 2 & siswa/i & Siswa-siswi \\
\hline
\end{tabular}

Berdasarkan tabel di atas terdapat

kesalahan dalam penggunaan tanda baca titik

(.) dan penggunaan huruf kapital di awal kalimat. Seperti terdapat pada kata “...tersedia" yang sesuai EBI seharusnya di tulis "...tersedia." karena untuk menandakan akhir kalimat yang terdapat pada baris ke sembilan. Selanjutnya kesalahan lainnya pada kata "siswa/i" yang sesuai EBI seharusnya di tulis "Siswa-siswi" yang terdapat pada baris ke-11. Selanjutnya, kesalahan yang terdaat dalam halaman ketiga terdapat dalam tabel di bawah ini.

Tabel 3

\begin{tabular}{|l|l|l|}
\hline No & Kesalahan & Sesuai EBI \\
\hline 1 & KETUA & Ketua \\
\hline 2 & SEKERTARIS & Sekertaris \\
\hline & & \\
\hline
\end{tabular}

Berdasarkan tabel di atas, terdapat kesalahan keseluruhan pengunaan huruf kapital. Seperti terdapat pada kata "KETUA" yang sesuai EBI seharusnya di tulis "Ketua" karena tidak seharusnya semua dituliskan menggunakan huruf kapital yang terdapat pada baris ke empat. Kemudian, kesalahan lainnya terdapat pada kata "SEKERTARIS" yang sesuai EBI seharusnya di tulis "Sekertaris" yang terdapat pada baris ke tujuh dan delapan. Selanjutnya, kesalahan yang terdapat dalam halaman kelima terdapat dalam tabel di bawah ini.

Tabel 4

\begin{tabular}{|l|l|l|}
\hline No & Kesalahan & Sesuai EBI \\
\hline 1 & jasmani & Jasmani \\
\hline
\end{tabular}

\begin{tabular}{|l|l|l|}
\hline 2 & ketua & Ketua \\
\hline 3 & wirausaha & Wirausaha \\
\hline 4 & kenakalan & Kenakalan \\
\hline 5 & difiani & Difiani \\
\hline 6 & kebersihan & Kebersihan \\
\hline
\end{tabular}

Berdasarkan tabel di atas, terdapat

kesalahan pada penggunaan huruf kapital yang digunakan di tengah kalimat. Seperti terdapat pada kata "jasmani" yang sesuai dengan EBI seharusnya di tulis "Jasmani" yang terdapat pada baris ke satu. Kesalahan lainnya terdapat pada kata "ketua" yang sesuai dengan EBI seharusnya di tulis "Ketua" karena di awal kalimat harus menggunakan huruf kapital yang terdapat pada baris ke satu dan tiga. Selanjutnya, terdapat kesalahan lainnya terdapat pada kata "wirausaha" yang sesuai EBI seharusnya di tulis "Wirausaha" yang terdapat pada baris ke-11. Kesalahan lainnya terdapat pada kata "kenakalan" yang sesuai EBI seharusnya di tulis "Kenakalan" yang terdapat pada baris ke-15. Kesalahan lainnya terdapat pada kata "difiani” yang sesuai EBI seharusnya di tulis "Difiani" karena menuliskan nama orang harus di awali dengan menggunakan huruf kapital yang terdapat pada baris ke-18. Selanjutnya, kesalahan lainnya terdapat pada kata "kebersihan" yang sesuai EBI seharusnya di tulis "Kebersihan" yang terdapat pada baris ke-19. Kesalahan selanjutnya, terdapat pada tabel di bawah ini.

\section{Tabel 5}

\begin{tabular}{|l|l|l|}
\hline No & Kesalahan & Sesuai EBI \\
\hline 1 & Masjid & masjid \\
\hline 2 & Sekbid & sekbid \\
\hline 3 & Eskul & eskul \\
\hline
\end{tabular}




\begin{tabular}{|l|l|l|}
\hline 4 & Siswi & siswi \\
\hline 5 & Diluar & Di luar \\
\hline 6 & hari besar & hari nasional \\
\hline 7 & Orang tua & orang tua \\
\hline 8 & Siswa & siswa \\
\hline
\end{tabular}

Berdasarkan tabel di atas, terdapat

penulisan pada kata "Masjid" kata yang seharusnya menurut EBI adalah "masjid" karena kata terebut berada di tengah kalimat dan seharusnya tidak menggunakan huruf kapital yang terdapat pada baris ke empat. Selanjutnya, terdapat kesalahan pada ejaan kata "Sekbid" yang seharusnya menurut EBI adalah "sekbid" karena terdapat di tengah kalimat dan tidak menggunakan huruf kapital yang terdapat pada baris ke sembilan. Kemudian, pada kata "Eskul" yang seharusnya menurut EBI adalah "eskul" karena seharusnya tidak menggunakan huruf kapital yang terdapat pada baris ke enam. Kesalahan selanjutnya adalah pada kata "Siswi" yang seharusnya dalam penulisan EBI adalah “ siswi" karena berada di tengah kalimat sehingga tidak menggunakan huruf kapital di awal penulisan yang terdapat pada baris ke-30. Selanjutnya, kesalahan yang ditemukan pada tabel di bawah ini.

\section{Tabel 6}

\begin{tabular}{|l|l|l|}
\hline No & Kesalahan & Sesuai EBI \\
\hline 1 & kebijaksana an & Kebijaksanaan \\
\hline 2 & di serahkan & Diserahkan \\
\hline 3 & wakil & Wakil \\
\hline
\end{tabular}

Berdasarkan tabel di atas, terdapat

kesalahan penggunaan huruf kapital.

Kemudian, kesalahan penggunaan kata depan.

Seperti terdapat pada kata "kebijaksana an" yang sesuai EBI seharusnya di tulis "Kebijaksanaan". Kesalahan lainnya terdapat pada kata "di serahkan" yang sesuai EBI seharusnya di tulis "diserahkan" yang terdapat pada baris ke-23. Kesalahan lainnya terdapat pada kata "wakil" yang sesuai EBI seharusnya di tulis "Wakil" yang terdapat pada baris ke27. Kesalahan selanjutnya, dapat terlihat pada tabel di bawah ini.

\section{Tabel 7}

\begin{tabular}{|l|l|l|}
\hline No & Kesalahan & Sesuai EBI \\
\hline 1 & di perlukan & diperlukan \\
\hline 2 & Untu & untuk \\
\hline 3 & Bendahara & bendahara \\
\hline 4 & memungut & meminta \\
\hline 5 & senin & Senin \\
\hline 6 & Jasmani & jasmani \\
\hline 7 & Kebersihan & kebersihan \\
\hline 8 & Diluar & di luar \\
\hline 9 & $\begin{array}{l}\text { kedisiplinan,kerapihan } \\
\text { dan ... }\end{array}$ & $\begin{array}{l}\text { kedisiplian, } \\
\text { kerapihan, } \\
\text { dan... }\end{array}$ \\
\hline
\end{tabular}

kesalahan dalam penulisan huruf kapital. Kemudian, terdapat kesalahan dalam penggunaan kata tidak baku dan penggunaan kesalahan penggunaan tanda baca koma (,). Kesalahan lainnya terdapat pada kata "di perlukan" yang sesuai EBI seharusnya di tulis "diperlukan" karena tidak menujukkan nama tempat sehingga kata depan disatukan yang terdapat pada baris ke tiga. Kesalahan lainnya terdapat pada penulisan ejaan kata "Untu" yang sesuai EBI seharusnya di tulis "untuk" yang terdapat pada baris ke empat. 
Kesalahan lainnya terdapat pada kata "Bendahara" yang sesuai EBI seharusnya di tulis "bendahara" karena kata tersebut berada di tengah kalimat sebelum tanda baca titik (.) yang terdapat pada baris ke delapan.

Kesalahan lainnya terdapat pada kata "senin" yang sesuai EBI seharusnya di tulis "Senin" karena kata tersebut berada di awal kalimat sehingga harus menggunakan huruf capital yang terdapat pada baris ke-16. Kesalahan lainnya terdapat pada kata "Jasmani" yang sesuai EBI seharusnya di tulis "jasmani" karena berada di tengah kalimat sehingga seharusnya tidak menggunakan huruf capital sebelum tanda baca titik yang terdapat pada baris ke-17. Kesalahan lainnya terdapat pada kata "Kebersihan" yang sesuai EBI seharusnya di tulis "kebersihan" yang terdapat pada baris ke-17. Kesalahan lainnya terdapat pada kata "Diluar" yang sesuai EBI seharusnya di tulis "di luar" yang terdapat pada baris ke-18. Kesalahan lainnya terdapat kesalah tanda baca koma (,) pada frasa "kedisiplinan,kerapihandan..." yang sesuai EBI seharusnya di tulis "kedisiplinan, kerapihan dan..." yang terdapat pada baris ke22. Selanjutnya, terdapat kesalahan yang dapat terlihat dalam tabel di bawah

Tabel 9

\begin{tabular}{|l|l|l|}
\hline No & Kesalahan & Sesuai EBI \\
\hline 1 & Ekstrakurikuler & ekstrakurikuler \\
\hline 2 & Kesenian & kesenian \\
\hline 3 & Kotak & kotak \\
\hline 4 & Curhat & curhat \\
\hline 5 & antarkelas & antar kelas \\
\hline 6 & Peringatan & peringatan \\
\hline
\end{tabular}

\begin{tabular}{|l|l|l|}
\hline 7 & di kepengurusan & dikepengurusan \\
\hline 8 & diluar & di luar \\
\hline
\end{tabular}

Berdasarkan tabel di atas, terdapat kesalahan penggunaan kata baku dan kesalahan penggunaan huruf kapital. Seperti terdapat pada kata "Ekstrakuriler" yang sesuai EBI seharusnya di tulis "ekstrakurikuler" karena berada di tengah kalimat sebelum tanda baca titik (.) yang terdapat pada baris ke dua. Kesalahan lainnya terdapat pada kata "Kesenian" yang sesuai EBI seharusnya di tulis "kesenian" yang terdapat pada baris ke dua. Kesalahan lainnya terdapat pada kata "Kotak" yang sesuai EBI seharusnya di tulis "kotak" yang terdapat pada baris ke enam. Kesalahan lainnya terdapat pada kata "Curhat" yang sesuai EBI seharusnya di tulis "curhat" yang terdapat pada baris ke enam. Kesalahan lainnya terdapat pada kata "antarkelas" yang sesuai EBI seharusnya di tulis "antar kelas" yang terdapat pada baris ke delapan. Kesalahan lainnya terdapat pada kata "Hari" yang sesuai EBI seharusnya di tulis "hari" karena berada di tengah kalimat sebelum tanda baca titik (.) yang terdapat pada baris ke sembilan.

Kesalahan lainnya terdapat pada kata "Peringatan" yang sesuai EBI seharusnya di tulis "peringatan" yang terdapat pada baris ke10. Kesalahan lainnya yaitu kesalahan penggunaan kata depan yang terdapat pada kata "diluar" yang sesuai EBI seharusnya di tulis "di luar" yang terdapat pada baris ke-12. Kesalahan lainnya terdapat pada kata "di kepengurusan" yang sesuai EBI seharusnya di tulis "dikepengurusan" yang terdapat pada 
baris ke-15. Selanjutnya, terdapat kesalahan yang terdapat dalam tabel di bawah ini.

Tabel 10

\begin{tabular}{|l|l|l|}
\hline No & Kesalahan & Sesuai EBI \\
\hline 1 & sesuai & Sesuai \\
\hline 2 & Kerohanian & kerohanian \\
\hline 3 & $\begin{array}{l}\text { volley,basket dan } \\
\text { futsal }\end{array}$ & $\begin{array}{l}\text { voli, basket, dan } \\
\text { futsal }\end{array}$ \\
\hline
\end{tabular}

Berdasarkan tabel di atas, terdapat

kesalahan penggunaan kata baku dan

kesalahan penggunaan huruf kapital. Seperti terdapat pada kata "sesuai" yang sesuai EBI seharusnya di tulis "Sesuai" karena berada di awal kalimat sehingga harus menggunakan huruf capital yang terdapat pada baris ke empat. Kesalahan lainnya terdapat pada kata "Kerohanian" yang sesuai EBI seharusnya di tulis "kerohanian" karena berada di tengah kalimat sebelum tanda baca titik (.) yang terdapat pada baris ke enam. Kesalahan lainnya terdapat kesalahan pada penggunaan tanda baca koma (,) pada kata "volley,basket dan futsal" yang sesuai EBI seharusnya di tulis "voli, basket, dan futsal" yang terdapat pada baris ke-10.

\section{Kata Baku}

Tabel 11

\begin{tabular}{|l|l|l|}
\hline No & Kesalahan & Sesuai EBI \\
\hline 4 & Shalat & salat \\
\hline 6 & Jum'at & jumat \\
\hline
\end{tabular}

Berdasarkan tabel di atas, terdapat kesalahan pada kata "Shalat" yang seharusnya dalam EBI adalah "Salat" karena kata pertama itu merupakan kata tidak baku dan terdapat kesalahan dalam penulisan huruf kapital yang seharusnya tidak menggunakan huruf kapital yang terdapat pada tengah kalimat yang terdapat pada baris kedelapan. Selanjutnya terdapat pada kata "Jum'at" penulisan yang seharunya menurut EBI adalah "jumat" karena kata pertama merupakan kata tidak baku yang terdapat pada baris ketujuh. Selanjutnya, kesalahan yang ditemukan pada tabel di bawah ini. Selanjutnya, halaman tujuh terdapat kesalahan kata baku yang terdapat dalam tabel di bawah ini.

\section{Tabel 12}

\begin{tabular}{|l|l|l|}
\hline No & Kesalahan & Sesuai EBI \\
\hline 1 & uang & Biaya \\
\hline 4 & kwitansi & kuitansi \\
\hline 5 & Investaris & inventaris \\
\hline 7 & Shalat & Salat \\
\hline 8 & Dhuha & duha \\
\hline 9 & memungut & meminta \\
\hline 10 & Infaq & infak \\
\hline
\end{tabular}

Berdasarkan tabel di atas, terdapat kesalahan pada kata "uang" yang sesuai EBI seharusnya di tulis "Biaya" yang terdapat pada baris kedua. Kesalahan lainnya terdapat pada kata tidak baku pada kata "kwitansi" yang sesuai EBI kata baku yang seharusnya di tulis yaitu "kuitansi" yang terdapat pada baris keempat. Kesalahan lainnya terdapat pada kata "Investaris" yang sesuai EBI seharusnya di tulis "inventaris" yang seharusnya digunakan tidak menggunakan kata tidak baku karena berada di tengah kalimat sebelum tanda baca titik (.) yang terdapat pada baris keenam.

Kesalahan lainnya terdapat pada kata tidak baku dalam penulisan "Shalat" yang sesuai EBI kata baku yang seharusnya di tulis yaitu "salat" yang terdapat pada baris ke-13. 
Kesalahan lainnya terdapat pada kata tidak baku dalam penulisan kata "Dhuha" yang sesuai EBI kata baku yang seharusnya di tulis dengan kata "duha" yang terdapat pada baris ke-13. Kesalahan lainnya terdapat pada kata "memungut" yang sesuai EBI seharusnya di tulis "meminta" yang terdapat pada baris ke16. Kesalahan lainnya terdapat pada kata "Infaq" yang sesuai EBI seharusnya di tulis "infak" yang terdapat pada baris ke-16. | Selanjutnya, halaman sembilan terdapat kesalahan kata baku yang terdapat dalam tabel di bawah ini.

Tabel 13

\begin{tabular}{|l|l|l|}
\hline No & Kesalahan & Sesuai EBI \\
\hline 5 & volley & voli \\
\hline 6 & $\begin{array}{l}\text { volley,basket dan } \\
\text { futsal }\end{array}$ & $\begin{array}{l}\text { voli, basket, dan } \\
\text { futsal }\end{array}$ \\
\hline
\end{tabular}

Berdasarkan tabel di atas, terdapat kesalahan pada kata "volley,basket dan futsal" yang sesuai EBI seharusnya di tulis "voli, basket, dan futsal" yang terdapat pada baris ke-10. Selanjutnya, terdapat kesalahan yang terdapat dalam tabel di bawah ini. Selanjutnya, halaman 12 terdapat kesalahan kata baku yang terdapat dalam tabel di bawah ini.

Tabel 14

\begin{tabular}{|l|l|l|}
\hline No & Kesalahan & Sesuai EBI \\
\hline 1 & Shalat dhuha & salat duha \\
\hline 2 & shalat Jum'at & salat jumat \\
\hline
\end{tabular}

Berdasarkan tabel di atas, terdapat pada frasa "Shalat dhuha" yang sesuai EBI seharusnya di tulis "salat duha" karena pada frasa pertama merupakan kata yang tidak baku yang terdapat pada baris ke-12.
Kesalahan lainnya terdapat kata tidak baku pada frasa "shalat Jum'at" yang sesuai EBI seharusnya di tulis "salat jumat" yang terdapat pada baris ke-15. Selanjutnya, halaman 25 terdapat kesalahan kata baku yang terdapat dalam tabel di bawah ini.

Tabel 15

\begin{tabular}{|l|l|l|}
\hline No & Kesalahan & Sesuai EBI \\
\hline 3 & Adzan & Azan \\
\hline
\end{tabular}

Berdasarkan tabel di atas,

terdapat kesalahan pada kata tidak baku yang terdapat pada kata "Adzan” yang sesuai EBI seharusnya di tulis "azan" yang terdapat pada baris ke-13. Selanjutnya, halaman 26 terdapat kesalahan kata baku yang terdapat dalam tabel di bawah ini.

Tabel 15

\begin{tabular}{|l|l|l|}
\hline No & Kesalahan & Sesuai EBI \\
\hline 6 & Menanggih & Meminta \\
\hline \multicolumn{3}{|c|}{ Berdasarkan tabel di atas, }
\end{tabular}

terdapat kesalahan pada kata "Menagih" yang sesuai dengan EBI adalah "meminta" yang terdapat pada baris keenam. Selanjutnya, halaman 31 terdapat kesalahan kata baku yang terdapat dalam tabel di bawah ini.

Tabel 16

\begin{tabular}{|l|l|l|}
\hline No & Kesalahan & Sesuai EBI \\
\hline 3 & bersodakoh & beredekah \\
\hline
\end{tabular}

Berdasarkan tabel di atas,

terdapat kata tidak baku pada kata "bersodakoh" yang sesuai dengan EBI adalah "bersedekah" yang terdapat pada baris ke-17. Selanjutnya, halaman 35 terdapat kesalahan kata baku yang terdapat dalam tabel di bawah ini.

Tabel 17 


\begin{tabular}{|l|l|l|}
\hline No & Kesalahan & Sesuai EBI \\
\hline 3 & ngider & berkeliling \\
\hline \multicolumn{2}{|c|}{ Berdasarkan tabel di atas, }
\end{tabular}

terdapat kesalahan kata tidak baku dalam penggunaan kata "ngider" yang seharusnya pada EBI adalah "berkeliling" yang terdapat pada baris kelima. Selanjutnya, halaman 44 terdapat kesalahan kata baku yang terdapat dalam tabel di bawah ini.

\section{Tabel 18}

\begin{tabular}{|l|l|l|}
\hline No & Kesalahan & Sesuai EBI \\
\hline 5 & mumentum & Momentum \\
\hline
\end{tabular}

Berdasarkan tabel di atas, terdapat kesalahan penggunaan kata baku pada kata "momentum" yang seharusnya menurut Berdasarkan hasil analisis di atas dalam laporan "Laporan Pertanggungjawabab OSIS di SMPN Kota Sukabumi Tahun Ajaran 2018/2019" masih banyak terdapat kesalahan dalam penggunaan ejaan, kesalahan yang paling banyak ditemukan adalah kesalahan dalam penggunaan huruf capital yang berada di tengah kalimat sebelum tanda baca titik (.). Kemudian, kesalahan dalam penggunaan kata baku tidak begitu banyak ditemukan dalam penulisan laporan.
EBI adalah "momentum" yang terdapat pada baris ke-16. Selanjutnya, halaman 45 terdapat kesalahan kata baku yang terdapat dalam tabel di bawah ini.

Tabel 19

\begin{tabular}{|l|l|l|}
\hline No & Kesalahan & Sesuai EBI \\
\hline 12 & Mushola & musala \\
\hline \multicolumn{3}{|c|}{ Berdasarkan tabel di atas, }
\end{tabular}

terdapat Kesalahan yang selanjutnya terdapat kata tidak baku dalam kata "Mushala" yang seharusnya dalam EBI adalah "musala" yang terdapat pada baris ketujuh. Selanjutnya, halaman 47 terdapat kesalahan kata baku yang terdapat dalam tabel di bawah ini.

\section{SUMBER RUJUKAN}

Chaer, Abdul. 2011. Ragam Bahasa Ilmiah. Jakarta: Rineka Cipta.

Sugiyono. 2016. Metode Penelitian Pendidikan. Bandung: Alfabeta.

Tarigan, Guntur, H. 2008. Menulis Sebagai Keterampilan Berbahasa. Bandung: Angkasa.

Waridah, Ernawati. 2016. Pedoman Umum. Ejaan Bahasa Indonesia. Depok: Penerbit Bmedia. 